\title{
Virtual Professional Training Community Model for Developing Digital Teacher Competencies
}

\author{
Napajit Dusadee $^{1, *}$, Pallop Piriyasurawong ${ }^{2}$ \\ ${ }^{1}$ Division of Information and Communication Technology for Education, King Mongkut's University of Technology North Bangkok, \\ Thailand \\ ${ }^{2}$ Faculty of Technical Education, King Mongkut's University of Technology North Bangkok, Thailand
}

Received June 17, 2020; Revised July 20, 2020; Accepted August 25, 2020

\section{Cite This Paper in the following Citation Styles}

(a): [1] Napajit Dusadee, Pallop Piriyasurawong, "Virtual Professional Training Community Model for Developing Digital Teacher Competencies," Universal Journal of Educational Research, Vol. 8, No. 9, pp. 4234-4241, 2020. DOI: 10.13189/ujer.2020.080950.

(b): Napajit Dusadee, Pallop Piriyasurawong (2020). Virtual Professional Training Community Model for Developing Digital Teacher Competencies. Universal Journal of Educational Research, 8(9), 4234-4241. DOI: 10.13189/ujer.2020.080950.

Copyright $\odot 2020$ by authors, all rights reserved. Authors agree that this article remains permanently open access under the terms of the Creative Commons Attribution License 4.0 International License

\begin{abstract}
This was a document research study. Its objectives were (1) to study the virtual professional training process to develop digital teacher competencies and (2) to synthesize digital teacher competencies. The data were analyzed by using the content analysis technique. The results of the research revealed the following. Digital Teacher Competency consisted of 6 aspects as follows: Part 1, Using digital technology; Part 2, Data information and knowledge; Part 3, Communication and collaboration; Part 4, Digital content creation; Part 5, Integrating digital pedagogy; and Part 6, Ethics using digital technology. The form of the virtual vocational training community to develop digital teacher competencies consisted of 4 parts, which were the following: 1) Input, 2) Process, 3) Output, and 4) Feedback. We were able to assess the suitability of the Virtual Professional Training Community Model for Developing Digital Teacher Competencies with 9 experts in information and communication technology in education. The evaluation results revealed that the Virtual Professional Training Community Model for Developing Digital Teacher Competencies was formed. Part 1, the suitability of the virtual professional training process to improve digital teacher competencies, was very suit-able. The mean was 4.63 and the standard deviation was 0.56 . Part 2, the suitability of the details of the virtual professional training process to develop digital teacher competencies, reached the most suitable level. The mean was 4.56 and the standard deviation was 0.65 .
\end{abstract}

Keywords Virtual Professional Training, Digital Teacher Competencies

\section{Introduction}

Digital technology advancement is an important factor that plays an important role in countries' economic and social development. Recently, the world has entered the digital economy and society era, where digital technology is no longer just a tool to support work as was the case in the past. Now, technology will truly be assimilated into people's lifestyles and result in structural changes in education. Digital technology has a direct impact on teaching, research, academic management and communication. As a result, many educational institutions around the world have chosen to use digital technology and teaching to help develop the quality and potential of education and educational personnel, meaning that digital technology influences life and work. The direction of Thailand's development into a developed country with long-term stability and prosperity is defined by the Constitution of the Kingdom of Thai-land, B.E. 2560, the 20-Year National Strategy Framework (2017 - 2036), the Economic Development Plan, the $12^{\text {th }}$ National Society (2017 - 2021) and the concept of Thailand 4.0: Model to Drive Security, Wealth and Sustainability. The introduction of digital technology is an important tool in the 
development of an economy based on the use of innovation, which has assisted the development of manpower, research, development and innovation including the basic education system in digital technology. These are the backbone of national development, which means that they must be adjusted to reflect the context of technological change in order to prevent the risk that may be caused by the use of inappropriate technology. Understanding and using digital technology is a basic digital skill that will be an important aid for civil servants in their operations, communications and collaboration with others. [1] The government policy focused on the production and development of the digital competencies of teachers includes the 20-year-long national strategy of the National Education Plan 2017-2036 and the $12^{\text {th }}$ Digital Development Plan for the National Economy and Society.

The Ministry of Education has established the National Education Plan 2017-2036 as a 20 year long plan that serves as the master plan for relevant agencies to guide the development of education. The plan has specified the operational guidelines for 6 strategies, which are strategies related to digital technology, such as strategy 3 , which is to develop the potential of people of all ages and to create a learning society. The goal is for students to have the skills and characteristics necessary in the $21^{\text {st }}$ century. There is a system for the production of the digital competencies of teachers and educational personnel so that they meet international professional standards and are able to work more efficiently. The above strategic plan is in line with the principles of teaching and learning in the $21^{\text {st }}$ century, where information technology plays an educational role.

Therefore, in the conditions described above, it is extremely important to be educated about the digital teacher competency development process. This is done in order to obtain important basic information that the agencies involved in the production and development of teachers can use and consider in the production and development of teachers so that they have the capacity to use this digital technology to keep up. It is necessary to comply with government policies, including the 20-year national strategy of the National Education Plan 2017-2036 and the $12^{\text {th }}$ Digital Development Plan for the National Economy and Society.

\section{Research Objectives}

The researcher has set the research objectives as follows:

1. To study the virtual professional training process to develop digital teacher competencies, and

2. To synthesize digital teacher competencies.

\section{Research Methods}

The research methodology is divided into 2 phases according to the research objectives.

Phase 1: Synthesis of digital teacher competencies.

It studies the data related to the synthesis of the digital competencies of teachers. The researcher studied the research papers, conducted content analysis, and synthesized the relevant research from 2008 to 2019.

Phase 2: Study the virtual professional training process to develop digital teacher competencies.

It studies the design of the virtual professional training process. It combines the concepts of applying TPACK (Technological Pedagogical Content Knowledge) and digital teacher competencies

Phase 3: Assessing the suitability of the Virtual Professional Training Community Model for Developing Digital Teacher Competencies.

It assesses the suitability by using 9 experts in information and communication technology, information technology and educational communication.

\section{Research Results}

\section{Phase 1: The results of the synthesis of digital teacher competencies}

From the documents, the studies and research on digital teacher competencies were synthesized. The synthesis of the digital teacher competencies in all 6 areas are shown in Table 1. 
Table 1. Digital Teacher Competency Synthesis

\begin{tabular}{|c|c|c|}
\hline \multicolumn{3}{|c|}{ 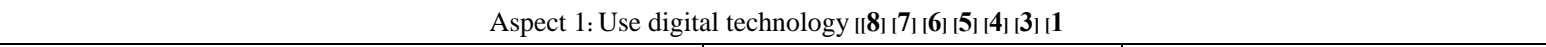 } \\
\hline Digital teacher knowledge ॥9 & Digital teacher skills & Digital teacher features $[1]$ \\
\hline $\begin{array}{ll}\text { 1. } & \text { Understand the components of computer systems } \\
\text { 2. } & \text { Understand computer networks } \\
\text { 3. } & \text { Understand websites and obtain knowledge } \\
\text { 4. } & \text { Understand how to use Microsoft Word processor. } \\
\text { 5. } & \text { Understand how to use Microsoft spreadsheet. } \\
\text { 6. } & \text { Understand how to use Microsoft PowerPoint. } \\
\end{array}$ & $\begin{array}{l}\text { Use a computer } \\
\text { Use information search } \\
\text { Use Microsoft Office } \\
\text { applications }\end{array}$ & $\begin{array}{l}\text { Focus on goals, think } \\
\text { critically, and solve problems. } \\
\text { 2. Open to new experiences, } \\
\text { originality, and self-learning } \\
\text { 3. Have morality and ethics }\end{array}$ \\
\hline \multicolumn{3}{|c|}{ 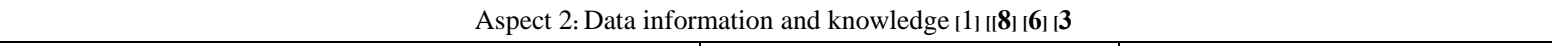 } \\
\hline Digital teacher knowledge ${ }_{1} 1_{1} \mathbf{0}$ & Digital teacher skills $[1 \mid \mathbf{0}$ & Digital teacher features $[1,0$ \\
\hline $\begin{array}{ll}\text { 1. } & \text { Understand the meaning and importance of } \\
\text { information } & \text { Understand the role of information } \\
\text { 2. } & \text { Know the types of information Search Engines. } \\
\text { 4. Use Search Engine techniques } \\
\text { 5. Know the benefits of information } \\
\text { 6. Understand the characteristics of data communication. } \\
\text { 7. Understand the importance of data communication } \\
\text { 8. } \\
\text { Understand the components of data communication }\end{array}$ & $\begin{array}{l}\text { Use information. } \\
\text { Evaluating data. } \\
\text { Data management. }\end{array}$ & $\begin{array}{l}\text { Focus on goals, think } \\
\text { critically, and solve problems. } \\
\text { Open to new experiences, } \\
\text { originality, and self-learning }\end{array}$ \\
\hline \multicolumn{3}{|c|}{ 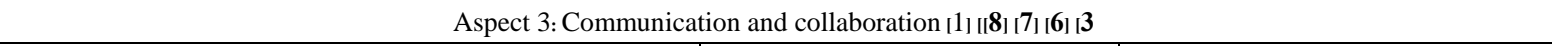 } \\
\hline Digital teacher knowledge ${ }_{[}{ }_{1} \mathbf{1}$ & Digital teacher skills & Digital teacher features $[1]$ \\
\hline $\begin{array}{l}\text { 1. Understand communication systems via wireless } \\
\text { networks } \\
\text { 2. Understand the components of the communication } \\
\text { 3rocess } \\
\text { 4. Understand the nature of communication } \\
\text { 5. Apply Microsoft Teams } \\
\text { Apply collaboration tools }\end{array}$ & $\begin{array}{l}\text { Interaction } \\
\text { Information sharing } \\
\text { Collaboration }\end{array}$ & $\begin{array}{l}\text { Communicate and collaborate } \\
\text { with others }\end{array}$ \\
\hline \multicolumn{3}{|c|}{ Aspect 4: Digital content creation I [12 $\mathbf{1 2}_{[}\left[\mathbf{8}_{\mid}[\mathbf{3}\right.$} \\
\hline Digital teacher knowledge $[1[1$ & Digital teacher skills & Digital teacher features [1] \\
\hline $\begin{array}{l}\text { 1. Have knowledge of the subject matter taught. } \\
\text { 2. Track the progress of the subjects taught } \\
\text { 3. Increase ability by sharing knowledge with teachers } \\
\text { who teach in the same subject. }\end{array}$ & $\begin{array}{l}\text { Content development } \\
\text { Content improvements }\end{array}$ & $\begin{array}{l}\text { Open to new experiences, } \\
\text { originality, and self-learning }\end{array}$ \\
\hline \multicolumn{3}{|c|}{ 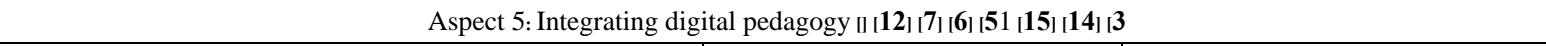 } \\
\hline Digital teacher knowledge $\left[13_{[}[1,6\right.$ & Digital teacher skills $[1,6$ & Digital teacher features $[1][1,1$ \\
\hline $\begin{array}{l}\text { 1. Understand the meaning of teaching design } \\
\text { 2. Understand the components of teaching and learning } \\
\text { 3. Transferring knowledge is in accordance with the } \\
\text { theories, principles, styles and teaching methods. } \\
\text { 4. Applying new teaching techniques and methods that } \\
\text { are appropriate for the teaching content }\end{array}$ & $\begin{array}{l}\text { 1. Teaching design } \\
\text { 2. Use of teaching techniques } \\
\text { and methods } \\
\text { 3. Content integration } \\
\text { 4. Knowledge transfer }\end{array}$ & $\begin{array}{l}\text { 1. Dare to make decisions and } \\
\text { take risks. } \\
\text { 2. Focus on goals, analyze, and } \\
\text { solve problems } \\
\text { 3. have a spirit of being a } \\
\text { teacher } \\
\text { 4. Be a good role model }\end{array}$ \\
\hline \multicolumn{3}{|c|}{ 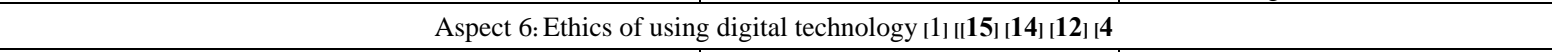 } \\
\hline Digital teacher knowledge $\left.{ }_{[1}\right]_{[} \mathbf{1} 1_{[} \mathbf{6}$ & Digital teacher skills & Digital teacher features $[1]$ \\
\hline $\begin{array}{l}\text { 1. Understand the meaning of the ethics of digital } \\
\text { 2. Understand the principles of the ethics of using digital } \\
\text { technology. } \\
\text { 3. Understand copyright infringement } \\
\text { 4. Understand the penalties } \\
\text { 5. Understand free software } \\
\text { 6. Understand the use of antivirus programs } \\
\text { 7. Understand the importance of protecting identity } \\
\text { information. }\end{array}$ & $\begin{array}{l}\text { 1. Safe when using digital } \\
\text { technology } \\
\text { 2. Know etiquette and rules } \\
\text { 3. Realize copyrights }\end{array}$ & Have morality and ethics \\
\hline
\end{tabular}

From Table 1, it can be found that there are 6 aspects of digital teacher competencies as follows. Aspect 1, the use of digital technology, consists of 1) using computers, 2) using the internet, and 3) using programs. Aspect 2, Data information and knowledge, consists of 1) browsing and searching for information, 2) evaluating data, and 3) data management. Aspect 3, communication and collaboration, consists of 1) interactivity, 2) information sharing, and 3 ) 
collaboration. Aspect 4, digital content creation, consists of 1) content development and 2) content improvement. Aspect 5, integrating digital pedagogy, includes 1) teaching design, 2) teaching techniques and methods, 3) content integration, and 4) knowledge transfer. Aspect 6, the ethics of using digital technology, consists of 1) the safe use of digital technology, 2) etiquette and practices, and 3) awareness of copyrights.

\section{Phase 2: Design the virtual professional training community model to develop digital teacher competencies}

The researcher studied, analyzed and synthesized the data, principles, concepts, and theories related to teaching and learning. The virtual training and capacity building of digital teachers is defined as the conceptual framework for system development using the conceptual elements obtained for the development of the training model by focusing on the System Approach. It is as shown in Figure 1.

Figure 1 shows the inputs, the training process, the evaluation and feedback of the virtual professional training process to improve digital teacher competencies.

The model of the virtual professional training process to develop digital teacher competencies consists of 3 main components, which are the following.
1) The inputs consist of 6 parts, which are the following.

1.1) Training courses include virtual professional training activities in which training was organized for trainees to acquire digital teacher competencies. They adhere to the principle that trainees are the most important and emphasize digital teacher knowledge, digital teacher skills and the characteristics of digital teachers.

1.2) The objective of the training is to enhance the capacity of digital teachers through the virtual professional training process.

1.3) The characteristics of the teachers participating in the training are as follows:

1. Focus on goals, think critically and solve problems; 2. Open to new experiences, initiate creativity, and learn by oneself; 3 . Have morality and ethics; 4. Dare to make decisions, take risks, and assume responsibilities; 5. Have the spirit of being a teacher; 6. Be a good role model and 7 . Communicate and work with others

1.4) The characteristics of speakers are that they are knowledgeable in virtual professional training; experts in learning management using digital technology; able to provide counseling, facilitate training and provide guidance on how to solve teaching and learning problems; and able to control the work of members to be successful.

\section{Input Process > Output}

1. Training course

2. Training objectives

3. Teacher features

4. Speaker features

5. Training plans and assessments

6. Virtual training environment

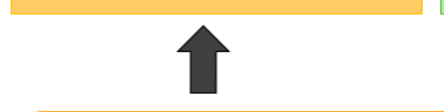

The training has 6 steps which are

1. Use technology

2. Search for information

3. Exchange knowledge

4. Design learning management

5. Create digital lessons

6. Present teaching methods

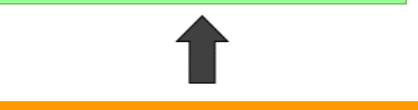

Digital Teacher Competency Assessment Form consists of the following

1. Digital Teacher Knowledge Test

2. Digital teacher skills assessment

3. Digital Teacher Feature Assessment Form

Feedback

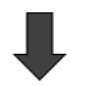

$+2$

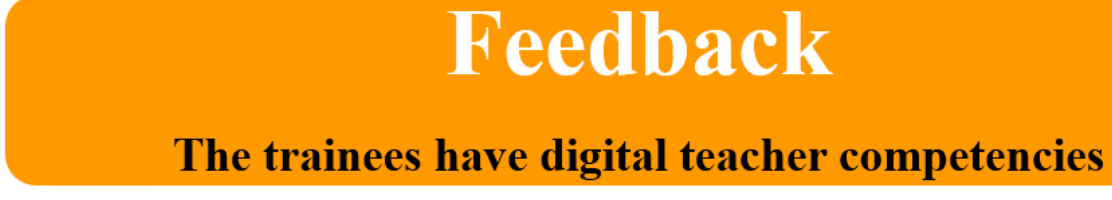

Figure 1. Virtual professional training process for digital teacher development 
1.5) Training and evaluation plans include the virtual professional training activities plans to develop digital teacher competencies, consisting of the following.

1.5.1. The aims of the training for digital teacher competencies are digital teacher knowledge, digital teacher skills, and digital teacher characteristics. They are used to define content and create training courses, and are important criteria for measurement and evaluation to check the quality of trainees.

1.5.2. Digital teacher competencies aim to develop trainees that have digital teacher competencies in the following 6 areas: Aspect 1. Using digital technology, Aspect 2. Information and knowledge, Aspect 3. Communication and collaboration, Aspect 4. Creating digital content, Aspect 5. Integrating digital teaching methods, and Aspect 6. Ethics of digital technology use.

1.5.3. Assessment and evaluation of the virtual professional training of trainees must be based on three basic principles: digital teacher knowledge assessment, digital teacher skills, and digital teacher characteristics.

1.6) The virtual training environment, including online communication tools, are tools to promote the management of virtual professional training to effectively give trainees access to digital teacher knowledge, digital teacher skills, and digital teacher characteristics according to the training objectives of the course

2) The training process consists of the following steps
2.1) Use technology such as using computers, the internet, and Microsoft Office programs.

2.2) Search for information, including browsing and searching for information for data evaluation and data management

2.3) Exchange knowledge, including knowledge on teaching designs, teaching techniques, teaching methods, the integration of content, and knowledge transfer.

2.4) Design learning management, including content development and content improvement.

2.5) Create digital lessons, including interaction, information sharing, and collaboration.

2.6) Present teaching methods, taking into account the security, manners and practices of using digital technology and copyrights.

3) The output consists of 3 evaluation parts as follows.

3.1) The digital teacher knowledge test is the knowledge test for the trainees.

3.2) The Digital Teacher Skill Assessment Questionnaire is a digital technology skill test.

3.3) The digital teacher feature evaluation form is the observation form after receiving training.

4) Feedback consists of 2 parts, which are the following.

4.1) The input evaluates training participation, informs the trainees of the training results, reports on training participation, and processes the training progress.

4.2) Process: The training evaluation results from the trainees are reflected back into the training process for the trainees. Problems and obstacles occurring during the training and solutions are reported to the relevant parties.

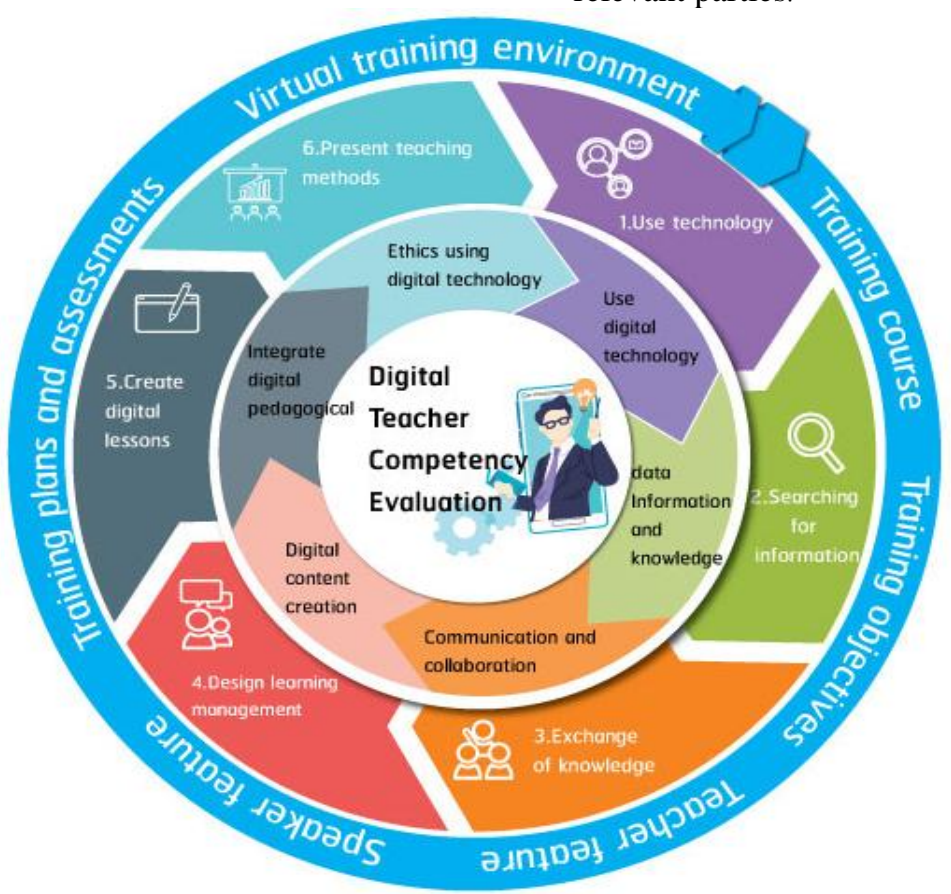

Figure 2. VPT-DTC model 
The virtual professional training community model to develop digital teacher competencies can be divided into 3 parts, as in Figure 2: 1. Inputs, 2. Processes, and 3. evaluation and feedback.

Figure 2 shows the virtual professional training process for developing digital teacher competencies.

In conducting virtual professional training activities to improve digital teacher competencies, one begins by defining the problems for the participants. The resulting continuous process consists of 6 steps, which are the following

(1). Use Technology: One must be able to use computers; understand computer system components; use the information search; understand computer network systems; and use Microsoft office programs, including Microsoft Word processor, Microsoft spreadsheet, and Microsoft PowerPoint.

(2). Search for information: One must be able to use information; understand the meaning, importance and role of information; identify the type of search; assess Search Engine information; use Search Engine techniques; know the benefits of information, data evaluation, and data management; and understand the characteristics, importance and components of data communication.

(3). Exchange knowledge: One must be able to design teaching programs; understand the meaning of the teaching design; understand the components of teaching; transfer knowledge in accordance with the theories, principles, styles, and methods of teaching; and use teaching techniques and methods. Furthermore, the knowledge should be applied using new teaching techniques and methods that are appropriate for the content taught, content integration, and knowledge transfer.

(4). Learning management design: One must be able to develop content, have knowledge of the content being taught, monitor the progress of the content being taught, improve the content, and increase others' abilities by sharing knowledge with teachers who teach in the same subject.

(5). Create digital lessons: One must be able to interact; understand communications via wireless networks; understand the components of the communication process; understand the nature of communication, data sharing and collaboration; apply Microsoft Teams; and apply collaboration tools.

(6). Present teaching methods: One must be able to teach the safe use of digital technology; understand the ethics, etiquette, practice and principles of using digital technology; realize copyrights; understand piracy; understand the penalties for misuse; understand the use of antivirus programs; and understand the protection of private identity information.

In carrying out virtual professional training activities to develop digital teacher competencies with a virtual training environment, digital teacher competencies are created in all 6 areas, including 1) Using digital technology, 2) Data information and knowledge, 3) Communication and collaboration, 4) Digital content creation, 5) Integrating digital pedagogy and 6) The ethics of using digital technology.

\section{Phase 3: Assessment of the suitability of the Virtual Professional Training Community Model for Digital Teacher Competency Development.}

Next, we analyze the suitability of the virtual professional training community model to develop digital teacher competencies. We define the suitability evaluation criteria using the Rating Scale, which measures the criteria for determining the weight of the assessment using a 5-point Likert Scale. The suitability evaluation results are shown in Table 2

Table 2. Assessment results of the suitability of the virtual professional training community model for digital teacher development.

\begin{tabular}{|l|c|c|c|}
\hline \multirow{2}{*}{ Details of the form } & \multicolumn{3}{|c|}{ Assessment results } \\
\cline { 2 - 4 } & $\begin{array}{c}\text { Average } \\
(\overline{\boldsymbol{X}})\end{array}$ & $\begin{array}{c}\text { Standard } \\
\text { Deviation }\end{array}$ & $\begin{array}{c}\text { Suitability } \\
\text { Level }\end{array}$ \\
\hline $\begin{array}{l}\text { 1. The principles and concepts used as the basis for designing a virtual professional training } \\
\text { process to improve digital teacher competencies. }\end{array}$ & 4.89 & 0.33 & High \\
\hline $\begin{array}{l}\text { 2. The components of the model are covered according to the main components of the } \\
\text { training classes in general. }\end{array}$ & 4.56 & 0.73 & High \\
\hline 3. Virtual Professional Training Process for Digital Teacher Competency Development. & 4.44 & 0.53 & Moderate \\
\hline Evaluation list summary & $\mathbf{4 . 6 3}$ & $\mathbf{0 . 5 6}$ & High \\
\hline
\end{tabular}

Part 1: Details of the virtual professional training process to develop digital teacher competencies. 


\begin{tabular}{|c|c|c|c|}
\hline \multirow[b]{2}{*}{ Details of the form } & \multicolumn{3}{|c|}{ Assessment results } \\
\hline & $\begin{array}{c}\text { Average } \\
(\bar{X})\end{array}$ & Standard Deviation & Suitability Level \\
\hline \multicolumn{4}{|l|}{ 1. Inputs } \\
\hline 1.1Training course & 4.78 & 0.44 & High \\
\hline 2.1 Training objectives & 4.89 & 0.33 & High \\
\hline 1.3 Characteristics of the teachers that received training & 4.56 & 0.73 & High \\
\hline 1.4 Speaker features & 4.44 & 0.73 & Moderate \\
\hline 1.5 Training plans and assessments & 4.67 & 0.71 & High \\
\hline 1.6 Virtual training environment & 4.44 & 0.73 & Moderate \\
\hline \multicolumn{4}{|c|}{ 2. Activities used for training in accordance with the virtual professional training process to develop digital teacher competencies. } \\
\hline 2.1 Use technology & 4.78 & 0.44 & High \\
\hline 2.2 Search for information & 4.44 & 0.73 & Moderate \\
\hline 2.3 Exchange and learn & 4.78 & 0.44 & High \\
\hline 2.4 Design learning management & 4.67 & 0.71 & High \\
\hline 2.5 Create digital lessons & 4.78 & 0.44 & High \\
\hline 2.6 Present teaching methods & 4.33 & 0.71 & Moderate \\
\hline \multicolumn{4}{|c|}{ 3. Assessment used in training according to the virtual professional training process to develop digital teacher competencies. } \\
\hline 3.1 Digital Teacher Knowledge Test (Test of the knowledge of trainees) & 4.50 & 0.76 & High \\
\hline 3.3 Digital teacher skills assessment (Digital Technology Skills Test) & 4.44 & 0.73 & Moderate \\
\hline 3.2 Digital Teacher Feature Assessment Form (Observation form for training) & 4.44 & 0.73 & Moderate \\
\hline \multicolumn{4}{|c|}{ 4. Feedback on the Virtual Professional Training Process for Digital Teacher Competency Development. } \\
\hline 4.1 Inputs (training evaluation results) & 4.44 & 0.88 & Moderate \\
\hline 4.2 Training process (Training assessment results from participants) & 4.56 & 0.73 & High \\
\hline Evaluation list summary & 4.56 & 0.65 & High \\
\hline
\end{tabular}

Part 2: Details of the main steps and sub steps of the virtual professional training process to develop digital teacher competencies.

\begin{tabular}{|c|c|c|c|}
\hline \multicolumn{1}{|c|}{ Details of the form } & \multicolumn{2}{c|}{ Assessment results } \\
\cline { 2 - 4 } & $\begin{array}{c}\text { Average } \\
(\overline{\boldsymbol{X}})\end{array}$ & Standard Deviation & Suitability Level \\
\hline $\begin{array}{l}\text { 1. The virtual professional training process to develop digital } \\
\text { teacher competencies is appropriate for the digital teacher } \\
\text { competency development at this level. }\end{array}$ & 4.78 & 0.44 & High \\
\hline $\begin{array}{l}\text { 2. The steps and activities of the virtual professional training } \\
\text { process to develop digital teacher competencies are suitable for } \\
\text { the development of developed digital teacher competencies } \\
\text { suitable for learning development at this level. }\end{array}$ & 4.44 & 0.73 & Moderate \\
\hline $\begin{array}{l}\text { 3. The virtual vocational training process to improve the capacity } \\
\text { of digital teachers to develop has practical applications. }\end{array}$ & 4.44 & 0.73 & Moderate \\
\hline Evaluation list summary & $\mathbf{4 . 5 6}$ & $\mathbf{0 . 6 4}$ & High \\
\hline
\end{tabular}

Part 3: Overview of the virtual professional training process to develop digital teacher competencies.

The data in Table 2 show the results of the evaluation of the suitability of the virtual professional training community model for digital teacher competency development. Part 1, the suitability of the details of the virtual professional training process to develop digital teacher competencies, is at the most suitable level, with a mean of 4.63 and a standard deviation of 0.56. Part 2, the suitability of the details of the virtual professional training process to develop digital teacher competencies, is at the most suitable level, with a mean of 4.56 and a standard deviation of 0.65 , which is in the range 0 to 1 , and thus can be considered reliable information. Therefore, it can be concluded that the experts when evaluating the suitability of the professional training to develop digital teacher competencies have similar opinions that it is suitable at the highest level.

\section{Conclusions and Discussion}

The results of the research assessed the Virtual Professional Training Com-munity Model for Digital Teacher Competency Development with the following 4 parts. 1) The inputs had 6 parts, including 1.1 Training 
courses, 1.2 Objectives, 1.3 The characteristics of the trained teachers, 1.4 Speaker features, 1.5 The training plan and evaluation, and 1.6 The virtual training environment. 2) The process consists of the following steps: 2.1 using technology, 2.2 searching for information, 2.3 Exchanging knowledge, 2.4 the learning management design, 2.5 creating digital lessons, and 2.6 presenting teaching methods. 3) The assessment consists of 3 assessments, which are 3.1 The Digital Teacher Knowledge Test, 3.2 The Digital Teacher Skill Assessment Form, and 3.3 The Digital Teacher Characteristics Evaluation Form. 4) Feedback consists of 2 parts, namely, 4.1 the inputs that are the training evaluation results, and 4.2 the evaluation process of the training from the participants. The evaluation of the 9 experts found that part 1 , the suitability of the details of the virtual professional training process to improve digital teacher competencies, is at the most suitable level with a mean of 4.63 and a standard deviation of 0.56. Part 2, the suitability of the main and substeps of the virtual professional training process to develop the digital teacher competencies, is the most suitable level, with a mean of 4.56 and a standard deviation of 0.65 , which is in the range 0 to 1 , and thus it can be considered reliable information. Therefore, it can be concluded that the experts have relatively similar opinions, which are suitable at the highest level, with experts advising the following points. For the 6-step virtual professional training process to develop digital teacher's competencies, ICT should be used as the main tool of the 6-step learning process and to identify the tools used so that it can be used effectively for those interested in the process. In Step 1, the technology used should be a technology that is suitable for the digital technology age and digital age students. Step 6 presents methods for teaching unrelated topics. The researcher further explained this by taking into account the safety, manners and practices of using digital technology and copyright awareness. The next step in the research will be to use the VPT-DTC model format to train online for teachers taught in science and technology.

\section{Acknowledgments}

I would like to thank the Graduate Collage of King Mongkut's University of Technology North Bangkok (KMUTNB), Thailand for providing financial support for the research fund.

\section{REFERENCES}

[1] Civil Service Commission, Guidelines for digital skills development of government officials and government personnel to transform into a digital government, Online available from https:/Www.ocsc.go.th/sites/default/files/attac hment/page/process_devskill_digital.pdf
[2] The Secretariat of the Council of Education, National Education Plan 2017-2036, Online available from http://backoffice.onec.go.th/uploaded/Outstand/2017-EdPlan6 0-79.pdf

[3] European Commission, Digital competence: the vital 21 st-century skill for teachers and students, Online available from

http://Www.ec.europa.eu/jrc/sites/jrcsh/files/DIGCOMP-FINA L-\%20UPDATED\%2002-06-2016.pdf

[4] Digital Government Development Agency (Public organization), Digital Literacy, Online available from https://e-learning.dga.or.th/xlms_ega/resource/tincan/eeb8959 5-2659-490f-b401-7634b6774cf6. index.html

[5] UNESCO, Estándares de competencia en TIC para docents, Online available from http://Www.eduteka.org/EstandaresDo centesUNESCO.php

[6] Ministerio de Educación Nacional Competencias TIC para el desarrollo profesional docente, Online available from http:/goo.gl/WbqS9L

[7] Fraser, J., Atkins, L., \& Richard, H. DigiLit leicester Supporting teachers, promoting digital literacy, transforming learning, Leicester City Council, 2013.

[8] INTEF, Marco Común de Competencia Digital Docente, Online available from

http://educalab.es/documents/10180/12809/MarcoComunCo mpeDigiDoceV2.pdf

[9] Panita Wannapiroon. Information technology and educational innovation. Textbook Production Center, King Mongkut's University of Technology North Bangkok, Thailand, 2016.

[10] Nutthapat Kaewrattanapat. Information Technology for Communication and Learning.Textbook Production Center, Suan Sunandha Rajabhat University, Thailand, 2018.

[11] Teachers Council of Thailand Regulations on Professional Standards (Issue 4) 2019. Government Gazette. Volume 136, special section 68 Ngor, 20 March 2019, pages 18-20. Ministry of Education, 2019

[12] Enlaces, Competencias y estándares TIC para la profesión docente. Centro de Educación y Tecnología (Enlaces). Ministerio de Educación, Gobierno de Chile, 2011.

[13] Prachyanan Nilsuk and Jira Jitsupa. Information and Communication Technology Administration for Education, Textbook Production Center, King Mongkut's University of Technology North Bangkok, Thailand, 2017.

[14] Enlaces. Estándares TIC para la Formación Inicial Docente Una propuesta en el contexto Chileno. Ministerio de Educación, Gobierno de Chile, 2008

[15] Redecker, C., \& Punie, Y. European framework for the digital competence of educators: DigCompEdu. In Ch. Redecker, \& Y Punie (Ed.), European framework for the digital competence of educators. Publications Office of the European Union, Luxembourg, 2017.

[16] Pallop Piriyasurawong. Learning strategy in information and communication technology for education, Textbook Production Center, King Mongkut's University of Technology North Bangkok, Thailand, 2017. 